KOSHIDA KENSUKE ${ }^{1}$

\title{
GLOBALIZATION OF TANKA. HOW TWITTER CONTRIBUTES TO DEVELOPMENT OF TRADITIONAL JAPANESE POETRY
}

\begin{abstract}
Tanka poems are a representative type of classical Japanese poetry with a long history. Beginning as waka, which were widely composed starting in the 7th century, today they continue to be produced by people of diverse backgrounds while retaining their ancient characteristics. In other words, tanka poems can be regarded as a valuable part of Japanese cultural heritage that are loved and enjoyed in contemporary Japan. My paper focuses on the current state of modern tanka and the significance of tanka in contemporary society. In the processes of globalization, the Internet is becoming the main platform for creating and reading modern tanka. Twitter, in particular, has become the largest such forum and features tanka from all over the world. It can be said that social media has had a great impact on modern tanka. As a result, the traditional framework of social exclusiveness of this poetic genre from ancient times has been removed, leaving an environment where people of any social status and cultural background can easily create and read tanka and join the tanka community.
\end{abstract}

Keywords: Twitter, tanka, modern tanka, globalization, social media

\section{INTRODUCTION}

The relationship between literature and social media must not be overlooked today. Recently, a variety of literary works including short stories and poems have come to be posted on social media by people around the world on a daily basis. People may also read a passage from a world

\footnotetext{
${ }^{1}$ PhD Candidate; Tohoku University; ke_koshida0705@yahoo.co.jp.
} 
masterpiece without having access to a print copy when someone shares it on Twitter. At the same time, it is possible for virtually everyone to post their work on social media to a potentially limitless number of readers. In this way, Japanese short poems have become particularly popular in global society and widely shared on social networking sites. It seems to be related to the characteristics of both social media and the poems themselves. This can be seen especially clearly in the case of Twitter, which has a limit of two hundred eighty characters, and its compatibility with Japanese short poetry expressed in three or five lines. The prominence of photographs on such websites as Facebook and Instagram also provides a fertile ground for short poetry, with many using photographs to enhance the effectiveness of haiku and other works. This paper focuses on tanka poetry, another important component of Japanese cultural heritage, one which nevertheless has undergone change and found new forms in foreign languages and on social media.

This phenomenon has been of much interest and concern to many young people in Japan since the second half of 2009, when Twitter first appeared and quickly became popular. Sasaki Arara (2010) points out that the number of people who post tanka on Twitter has increased rapidly in Japan since 2010. This topic has also received attention in newspapers, including the popular Sankei Shimbun News (2016), in which the following was written:

The number of young people writing tanka has been increasing. Social media such as Twitter sparked this boom. [...] It may be as easy for young people to write a tanka poem as it is to post a short sentence on social media. In fact, tanka is spreading across generations and has gradually started to be loved by a younger public.

(translated by Koshida Kensuke)

So far, several books and articles in Japan have introduced the idea that the spread of social media that allows easy posting and communicating has allowed for the creation of new types of tanka; for example, poems that alter the rules for composing tanka or others that use slang and informal language. Moreover, Masuno Koichi (2018) has stated that "It seems that posting tanka on various social media has become popular among young people these days", while pointing out that the number of postings of tanka with photographs on Instagram is increasing. 
While the relationship between tanka and social media in Japan has thus been discussed, not enough attention has been paid to the tanka in foreign languages that social networking has made possible. It needs to be recognized that tanka is in the process of becoming part of world literature and is no longer exclusively the national poetry of Japan. To better understand the significance of tanka in modern society, it is essential to pay attention to tanka on social media all over the world.

This paper examines the relationship between social media and modern tanka in the processes of globalization. The paper first explains in detail the composition of tanka and its history from the 8th century to the present day. Then it discusses the point of expression of tanka poems through introducing one of the most famous works in Japan. Lastly, it introduces tanka works posted on Twitter and analyzes why this type of poetry has become popular on social networking sites and what new places it may find in the globalized world.

\section{THE COMPOSITION OF TANKA AND THE HISTORY OF ITS DEVELOPMENT}

There are roughly three types of short Japanese poetry that are specifica lly mentioned in this paper. That is tanka (短歌), haiku (俳句), and senryū ( 川柳). Tanka has a long history having been widely composed since the 8th century onwards, and is still written by various people, mainly in Japan. On the other hand, haiku and senryū are the major genres of traditional Japanese poetry which were born under the influence of tanka and were popular in the Edo period (1603-1867 CE). Although haiku include kigo (季語), which are words or phrases associated with a particular season, senryū do not generally include this. Therefore, haiku tend to be about nature while senryū tend to be about human affairs and are cynical or darkly humorous. Moreover, there is an important rule of these Japanese forms of short poetry in which tanka is a poem in 31 sound units or morae, arranged in lines of 5, 7, 5, 7 and 7 morae, while haiku and senryū contain 17 morae, in three lines of 5, 7 and 5 morae.

For example, haiku, short three-line poems now composed in many countries, are posted on Twitter every day by poets from all over the world. Alongside haiku, social media has also become the main reading 
and writing platform for other Japanese short poetry forms such as tan$k a$ and senryu, and, with them, the community of readers and writers has spread around the world.

The short poetry forms mentioned so far may have thus become popular forms of world literature, but they also represent elements of the cultural heritage of Japan. In particular, tanka poems are a representative form of classical Japanese poetry with a long history. Beginning as waka poetry, which were widely written starting in the 8th century, they continued to be composed by people of diverse backgrounds into the Edo period.

As a first step, we need to investigate the composition of tanka poetry. One of the most important rules defines tanka as a poem of 31 morae in Japanese, arranged in lines of 5-7-5-7 and 7 morae. One of the most famous tanka poems in Japan serves as an example.

$\begin{array}{lll}\text { 観覧車 } & \text { Kanransha } & \text { Ferris wheel, } \\ \text { 回れよ回れ } & \text { Mawareyo maware } & \text { go round and round! } \\ \text { 想ひ出は } & \text { Omoide wa } & \text { memories last one day for you, } \\ \text { 君には一日 } & \text { Kimi ni wa hitohi } & \text { a lifetime } \\ \text { 我には一生 } & \text { Ware ni wa hitoyo } & \text { for me. }\end{array}$

(translated by Uzawa Kozue and Amelia Fielden)

The units of sound are counted as morae, rather than syllables, and accord with a single kana in the Japanese syllabary. Divided into these sounds for clarity, the above poem would appear as:

\author{
$\underline{\text { Ka }} \underline{\text { n }} \underline{\text { ra }} \underline{\mathrm{n}} \underline{\text { sha }}$ \\ Ma wa re yo ma wa re \\ O mo i de wa

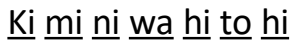 \\ Wa $\underline{\text { re }}$ ni wa $\underline{\text { hi to }}$ ㅁo
}

It is possible to feel the fixed rhythm as 5-7-5-7 and 7 morae when reading it aloud while paying attention to the breaks inserted above. As the rules also stipulate that tanka be composed in a structure of five lines, they are sometimes called "five-line poems" overseas.

The depth to which tanka have permeated Japanese culture can be seen in their publication and incorporation in Japanese newspapers, TV, and radio programs. For example, newspapers offer regular tanka columns 
featuring works by the public, including many under the theme of events in daily life. Therefore, we can say that anyone in Japan can be a poet. Donald Keene, a famous scholar of Japanese literature with a long affiliation with Tohoku University, stated that "Poetry in Japan is the property of all classes of society, and even today almost any Japanese can write a poem without difficulty" (Keene, 1955, p. 25). In contemporary Japan, traditional poetry forms such as tanka and haiku continue to be extremely important. They are valuable elements of Japanese cultural heritage, and tanka in particular has a long tradition and can be enjoyed by any Japanese person.

Tanka first emerged from the older form of waka poetry, upon which it is directly based. Waka (meaning "Japanese poems/songs") is a form of poetry that was prominent in Japanese classical literature first being recorded in the early 8th century in a collection known as the "Man'yōshū" (万葉集). Waka poems were part of the general education of ancient people and had a great influence on the classics of Japanese literature, such as "The Tale of Genji" (源氏物語) and haiku, which are known all over the world.

Waka were composed under a variety of themes (e.g. nature, love, friendships, mourning, and so on), and are themselves not greatly different from the poetry appearing in present day newspapers. However, a key feature of waka is that they make you feel the season. The way in which poets usually did this was to rely on a seasonal framework to express these themes.

Here is an example which is one of the most famous waka poems in Japan.

$\begin{array}{lll}\text { 五月待つ } & \text { Satsuki matsu } & \text { If I smell the fragrance--- } \\ \text { 花橘の } & \text { Hana-tachibana no } & \text { of the mandarin orange flowers } \\ \text { 香をかげば } & \text { Ka o kageba } & \text { whose bloom waits for the Fifth Month, } \\ \text { 昔の人の } & \text { Mukashi no hito no } & \text { I am reminded of the fragrance } \\ \text { 袖の香ぞする } & \text { Sode no ka zo suru } & \text { of the person I loved a long time ago. }\end{array}$

(Kokin Wakashū [古今和歌集], M. F. Marra, Trans.)

\footnotetext{
${ }^{2}$ At the workshop, we discussed Kake-kotoba (掛詞) (pivot words), which are an important rhetorical device used in waka. The presentation of multiple meanings inherent in a single word (e.g. 松, matsu, meaning "pine tree" / 待つ, matsu, meaning "to wait") allows the poet a fuller range of artistic expression with an economical syllable-count. While this was a key feature of waka, it is not frequently found in tanka.
} 
The first point of interpretation is in lines 4 and 5, "Mukashi no hito no / Sode no ka zo suru". This tells us that the poet has just remembered their former lover by the fragrance of the mandarin orange blossoms. The second point is the word "Hana-tachibana", referring to a blooming that evokes a real feeling of the beginning of summer. Considering these two points, this waka is based on a seasonal framework and represents the poet's feelings as something that everyone can easily empathize with.

However, because of its seasonal framework, waka poetry became encoded in stereotypes, resulting for those who did not have any knowledge of them in not being able to compose or interpret waka poems. In other words, waka became a privilege of only the intellectual class. It has been observed that in the 19th century, due to the constrained situation of the community of waka poets and the influence of poetry transmitted from abroad to Japan, innovation in traditional short poetry spread among rising poets, transfiguring the waka poem into tanka. The background of this change also includes modernization in the Meiji period (1868-1912) and the very influential poet and critic Masaoka Shiki (正岡子規, 1867-1902). Masaoka criticized the seasonal framework severely and tried to get rid of it, insisting that tanka should express personal experiences. Regarding this, John Holt states that "No other modern Japanese poet displayed a fresh, original approach to private moments of time better than Shiki" (Holt, 2016, p. 28).

Many tanka poets followed Shiki and expressed their personal experiences in their poems, and this trend made it easier for various people to participate in the tanka community. Therefore, Shiki's criticisms marked an important turning point for short poetry in Japan, and, even in the present day, continue to have an impact on modern tanka. Due to his influence, personal incidents and private moments of awareness displaced seasons as a primary theme.

\section{IMPORTANT POINTS OF EXPRESSION IN TANKA - THE EXAMPLE OF TAWARA MACHI}

We now turn to the point of expression and interpretation of tanka poetry. Here, the example of Tawara Machi (俵万智, born in 1962), one of the most popular tanka poets and a writer who enjoys international fame, will 
be used by way of illustration. Presented below is the poem that is considered Tawara's masterpiece and is taught to students of junior and senior high school in Japan.

$\begin{array}{ll}\text { 「寒いね」と } & \text { “Samui-ne” to } \\ \text { 話しかければ } & \text { Hanashikakereba } \\ \text { 「寒いね」と } & \text { “Samui-ne" to } \\ \text { 答える人のいる } & \text { Kotaeru hito no } \\ \text { あたたかさ } & \text { Iru atatakasa }\end{array}$

\author{
"Cold out, isn't it?" \\ You say, and get an answer, \\ “Cold out, isn't it?" \\ How warm it makes you feel \\ That someone is there to answer.
}

(Tawara, 1987, J. Stamm, Trans.)

The meaning of this tanka is that even though it is cold outside, it makes one's heart warm to have someone to answer them. It should be said that this fits the profile of a moment of private awareness in everyday life. Tawara $(1993$, p. 86) points out that the first step in composing a tanka should be to express the wavering of the heart in daily lives, as Shiki appealed for the importance of private moments. "Wavering of the heart", in other words, means that you have the feeling that gives you some kind of "ah!" moment. It is because so many people in the world empathize with the "ah!" moments of Tawara's poems such as these that she has been popular for a long time.

Since tanka has only five lines, the poet cannot express many things. Therefore, even private incidents can have a spotlight shone upon them, and the tiniest impression of them sparks empathy in various people's minds. This is one of the most important points of expression of tanka poems.

We have in our daily lives countless "ah!" moments that can form a tanka. At the same time, these are often the things that we might post on all kinds of social media. In this way, it can be said that social networking sites and tanka have similarities in their use as platforms for conveying impressive personal events and diverse feelings to others and evoking empathy in them. Considering this background, it is not hard to understand why people who enjoy tanka live not only in Japan but also all over the world. In the next section, we will take a closer look at the relationship between modern tanka and social media, especially Twitter. 


\section{THE RELATIONSHIP BETWEEN TANKA AND SOCIAL MEDIA}

The appeal of Machi Tawara provides the departure point for an exploration of how modern tanka poems are expressed and the reason why they have become popular on social media. The following section offers some examples of tanka on Twitter as global social networking.

Twitter has had the biggest impact on modern tanka. Hashtags attest the popularity of tanka on the site and searches for \#tanka or \#fivelines bring up scores of poems. There are numerous accounts that introduce famous waka and tanka poetry, and many people use the platform to post their own works. These include works composed in Japan and around the world.

Tanka on Twitter and other social media highlight how poets shape moments from daily life into the form of tanka and share them with people from different countries. This relationship between modern tanka and social media has led to an expansion of the tanka community. At the same time, tanka is being reinvented as a new literary form by the impact of social networking sites. In that sense, \#tanka or \#fivelines is a testament to the global appeal of tanka poetry as a means of self-expression.

The following is an example of a tanka poem posted on Twitter.

$\begin{array}{lll}\text { 会えたから } & \text { Aeta kara } & \text { Because I saw you right away, } \\ \text { 見落としていた } & \text { Miotoshiteita } & \text { I missed your text } \\ \text { 「着いた」って } & \text { “Tuita” te } & \text { that said, “I just got here!” } \\ \text { メールに今日が } & \text { Meeru ni kyou ga } & \text { When I found it later on my way home, } \\ \text { あふれだす帰路 } & \text { Afuredasu kiro } & \text { the memories flooded my mind }\end{array}$

Source by ひざみろ(@100kat2), (2019, September 12, 2:08 AM. Tweet., K. Koshida, Trans.)

This tanka focuses on the feeling experienced by the author upon the discovery of an email that reminds them of the joyful events of that day. Readers can sympathize with the poet who enjoyed going out somewhere with their friends through the expression of this work.

Moreover, we must note that the number of likes this tanka has gotten on Twitter is one hundred six and counting. The "Like" button, in other words, is a barometer of the degree to which people were moved by the poem. The number of one hundred six likes might be considered one 
hundred six units of empathy from readers. In this way, it can be said that an advantage of social media as a forum for poetry is that authors can see readers who empathize with the poet's moments of awareness in everyday life. The ease of posting, as well as the formation of a close community of poets and readers are both reasons why tanka poetry has become popular on social media.

The following is an example of tanka from social media from outside of Japan.

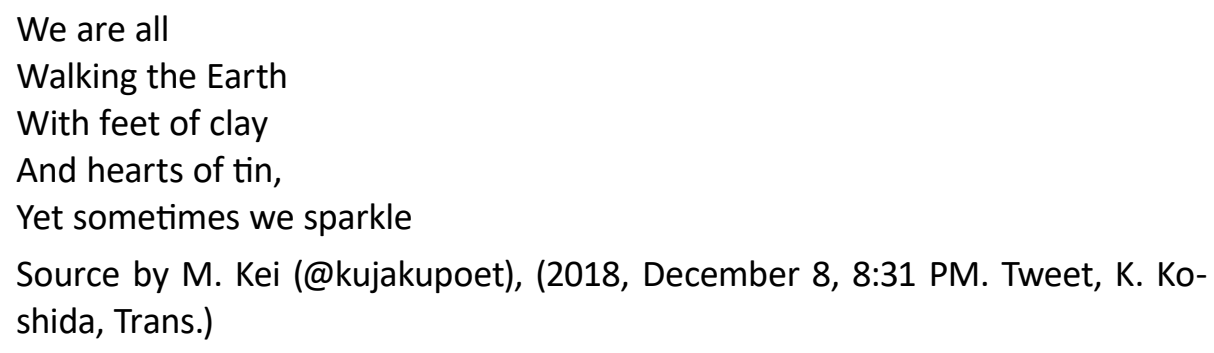

The first point of the interpretation is the phrase "With feet of clay / And hearts of tin". It expresses weak points (= "With feet of clay") and being unconfident (= "And hearts of tin"). The author may be depressed by their weakness, but such negative things are appropriate as themes for modern tanka, because they are personal experiences. The second point is the phrase "Yet sometimes we sparkle". Certainly, there are not many days when everything goes perfectly smoothly, but still sometimes we manage to sparkle. This tanka thus attempts to express some aspects of the subtlety of human life.

There may be some doubt, based on the explanations earlier in this chapter, as to whether this can really be considered a modern tanka, rather than just a five-line poem. It is hard to be certain that poets writing in English and other languages on social networking sites know about prosody and other specific traditions of Japanese waka and tanka poetry. However, I argue that we should recognize all these poems, whether they are or are not tagged with either \#tanka or \#fivelines, to be considered works of modern tanka. Putting aside the problem of the validity of translated poetry and linguistic differences between Japanese and other foreign languages, the fact that poets post their intention to express their feeling in the form of a tanka poem, in my opinion, makes it enough to appreciate their works as modern tanka. It has also played a role in preserving and 
maintaining the tradition of short Japanese poetry in the present and has caused tanka to be embraced as cultural heritage not only in Japan but also worldwide.

A final example follows.

No matter

What father just said...

His right hand

Keeps erasing the words

On the blackboard of his mind.

Source by Chen-ou Lui (@ericcoliu), (2019, March 23, 2:56 PM. Tweet, K. Koshida, Trans.)

The first feature is the ellipsis points ("What father just said..."), which express that the author's father was hard to read, and the thoughts in his mind at that time were expounded in the following phrases. The second point is "the words / On the blackboard", which disappear without a trace. This is an expressive phrase that the father may have been afflicted with dementia. In any case, this tanka represents a delicate relationship between father and his son. In addition, it feels real because the theme is family, something that evokes universal empathy.

By posting and sharing tanka all over the world, the day has also come when someone's observations and feelings in daily life can be expressed easily. ${ }^{3}$ While tanka has changed dramatically due to the impact of social media, the activities of composing and reading it have been repeated by people throughout its long history.

\section{CONCLUSION}

Cultural heritage refers to the practices, representations, expressions, knowledge, and skills which communities, groups, and, in some cases, individuals recognize as important parts of their culture. These are not only transmitted

\footnotetext{
${ }^{3}$ At the workshop, it was asked whether one could respond to a posted tanka with a poem of one's own. In fact, there are many examples of this kind of exchange, and it is consistent with the tradition of waka and tanka. In ancient societies, the exchange of waka poems was an important activity between lovers.
} 
from generation to generation, but continue to be creatively developed and globalized in new forms today by means of social networking sites.

This paper has investigated the composition and appreciation of tanka poetry on social media. After briefly reviewing its history from the 8th century to the present day that begins with waka poetry, the paper discusses the nature of contemporary tanka expression through the important works of Tawara Machi. Finally, it offered reasons why Japanese short poetry has become popular around the world and the relationship between tanka and social media.

A key feature of waka is the seasonal framework which poets usually depended on to express a variety of themes. However, over time, waka poetry became stereotyped, and those who did not have any knowledge of these seasonal codes could not compose and interpret them. Therefore, Masaoka Shiki promoted a movement focused on introducing innovation into traditional short poetry during the Meiji period. He criticized the seasonal framework severely and tried to force its abandonment, insisting that tanka should express personal experiences. Shiki's approach made it easier for a wider variety of people to participate in the tanka community. This was an important turning point for short poetry in Japan and, even in the present day, it still has an impact on modern tanka.

Tawara Machi has also focused attention on moments of private awareness in daily life - ones which she calls "ah!" moments - and has appealed for their importance to be recognized in tanka. As the short fiveline structure of tanka shines a spotlight on such moments, the tiniest impression of them directly creates empathy in various people's minds. This is one of the most important points of expression of tanka poems.

In addition, social media and tanka resonate with one another in their capacity to convey impressive personal events and diverse feelings to others. In other words, there is a comparability between the aim of social networking and the spirit of tanka, namely to express one's desires and experiences, and to share them with the world. This is the reason why modern tanka has become popular on social media, especially Twitter. Moreover, particular aspects of social media, such as hashtags and the "Like" button, are also related with the popularization of tanka all over the world and the formation of a global tanka community of poets and readers.

Through globalization, we have been able to share tanka and participate in its community of poets and readers on social media around the world. While some doubts have emerged concerning the authenticity of 
such international and net-based tanka (e.g. different languages, number of syllables, lack of prosody, and so on), historically classic tanka poetry has already undergone some dramatic changes in its derivation from waka poetry, despite its preservation of the 5-7-5-7-7 line format. Therefore, it can be said that modern tanka is being composed and read all over the world as a new style of one of the established genres, while still maintaining its spirit. It is important to note that the relationship between tanka and social media has had a positive effect on both elements.

Today, tanka poems are being composed and appreciated all over the world, and its community is expanding. While Japanese short poetry has been handed down as a tradition shaped over many centuries, it is now not only a literary genre in Japan, but also a piece of cultural heritage shared around the world. This is one of the roles that tanka plays in globalization. As tanka poetry is increasingly written, read, posted, and shared all over the world, it may become an important part of the world's cultural heritage. Further research is needed that explores different social media, other than the ones focused on in this chapter, and how tanka is posted and shared around the world.

\section{BIBLIOGRAPHY}

Harada, J. [原田純一] (2016). Wakamono ni Tanka Boom: Kikkake wa SNS [「若者に短歌ブ 一ム.....きっかけはSNS」, Tanka boom: Social Media Has Become a Catalyst for young people]. Sankei News [産経二ュース]. Retrieved from https://www.sankei.com/life/ news/161207/lif1612070010-n1.html.

Holt, J. (2016). Literature Short on Time: Modern Moments in Haiku and Tanka. In J. Holt, Routledge Handbook of Modern Japanese Literature (pp. 26-41). Routledge. https://doi. org/10.4324/9781315762210.ch2.

Keene, D. (1955). Japanese Literature: An Introduction for Western Readers. Tokyo: Charles E. Tuttle Company.

Kuriki, K. [栗木京子] (1984). Mizu-Wakusei [『水惑星』，Water planet]. Tōkyō: Ganshokan [東 京: 雁書館].

Kurose, K. [黒瀬珂瀾] (2012, February 16). Gendai Tanka Eiyaku Sakuhin-Shū [ $「$ 現代短歌英訳 作品集」, English Translation Collection of Modern Tanka]. Shizukani Hane o Kobosu Mainich [しづかに羽をこぼす毎日] (Japan). Retrieved from https://karankurose.hatenadiary. org/entry/20120216/1329439596.

Marra, M. F. (2008). Seasons and Landscapes in Japanese Poetry: An Introduction to Haiku and Waka. Lewiston: Edwin Mellen Press.

Masuno, K. [杵野浩一] (2018, March 30). SNS ga Tsumugu Tanka New Wave [ $\ulcorner$ SNSが紡ぐ 短歌二ューウェーブ」, The New Wave of Tanka Produced by Social Media]. LINE Min'na no Monogatari [L INEみんなのものがたり] (Japan). Retrieved from https://stories-line. com/understand/00008/. 
Sasaki, A. [佐々木あらら] (2010, March 19). Tegarusa ga Miryoku no 'Twitter Tanka' [ $\ulcorner$ 手軽さ が魅力の「ツイッター短歌」」, Easy to tweet 'Tanka on Twitter']. Imidas Opinion [Imidas オピニオン] (Japan). Retrieved from https://imidas.jp/jijikaitai/l-40-114-10-03-g379.

Tawara, M. (1987/1988). Sarada Kinenbi [俵万智.『サラダ記念日』, Salad Anniversary] (J. Stamm, Trans.). Tōkyō: Kawade Shobo Shinsha [東京: 河出書房新社].

Tawara, M. (1993). Tanka o Yomu [俵万智.『短歌を読む』, How to Read Tanka Poems]. Tōkyō: Iwanami Shoten [東京: 岩波書店]. 